\title{
Response of a Seeded Mixture of Warm-season Prairie Grasses to Fertilization'
}

\section{G. W. REHM, W. J. MOLINE, AND E. J. SCHWARTZ}

Assistant Professor of Agronomy, Northeast Experiment Station, Unizersity of Nebraska, Concord, Nebraska; Professor of Agronomy and Former Assistant Professor of Agronomy, University of Nebraska, Lincoln.

\section{Highlight}

A seeded mixture of warm-season prairie grasses containing big bluestem (Andropogon gerardi, Vitman), switchgrass (Panicum virgatum L.), Indiangrass (Sorghastrum nutans, L.), and sideoats grama (Bouteloua curtipendula, L.) was fertilized over a four-year period with $N, P, K, S$ and $Z n$. Yields were increased by $N$ and combinations of $N$ and $P$, but not by $K, S$, or $Z n$. Fertilization did not alter indexes of quality (\% protein and \% digestible dry matter) in the mature tissue. After four years, the percentage of each species in the mixture had not been altered by fertilizer treatment. Encroachment by cool-season species and weeds was not encouraged by fertilization which was largely attributed to the fact that fertilizers were applied after May 15 of each year.

Perennial warm-season prairie grasses are an important part of the total forage resources which provide summer grazing in the Plains states. There are many management factors which influence the production of these grasses. Proper fertilization is but one important practice.

${ }^{1}$ Published as Paper Number 3271, Journal Series, Nebraska Agricultural Experiment Station. Research reported was conducted under Project No. 12-45. Received for publication October 27, 1972.
Fertilizer studies employing both pure and mixed stands of several prairie grasses, both seeded and natural have been reported in the literature. These reports, however, have been conflicting. A Wyoming study by Rauzi et al. (1968) demonstrated that production from warmseason grasses in native pastures was not increased by $\mathbf{N}$ fertilization. However, in a British Columbia study, applied $\mathrm{N}$ was effective in increasing forage production on some, but not all, native ranges (Hubbard and Mason, 1967). In their study, residual effects of fertilizer application produced yield increases six years after initial usage. Residual effects of range fertilization were found to be beneficial in research reported by Read (1969).

Rogler and Lorenz (1957) reported that $\mathrm{N}$ increased the production of Northern Great Plains rangelands. Similar responses have been reported by Goetz (1969) and Johnston et al. (1968). In Montana, Black (1968) found that combinations of $\mathbf{N}$ and $\mathbf{P}$ produced forage yields significantly greater than yields from the use of $\mathbf{N}$ alone. The responses were greatest in the year of fertilization, but residual effects on forage yield were significant one to two years later. In Nebraska, Warnes and Newell (1969) and Warnes et al. (1971) studied the effects of $\mathrm{N}$ and $P$ on stand establishment and yield of five warm-season grasses. They reported that proper timing of annual fertilizer $\mathbf{N}$ applications after the year of establishment maintained superior stands and increased forage yields.

There has, however, been some hesitancy to recommend $\mathbf{N}$ for warm-season prairie grasses due to reported encroachment by cool-sea- 
son species (Huffine and EIder, 1960) and some weeds (Owensby et al., 1970) in the fertilized stands of the desired warm-season species.

Realizing the inconsistency of reports in the literature and the need for further work with additional nutrients, this study was designed to measure the response of a seeded mixture of warm-season prairie grasses to the application of $\mathrm{N}, \mathrm{P}, \mathrm{K}, \mathrm{S}$ and $\mathrm{Zn}$.

\section{Experimental Procedure}

This study was initiated in 1967 on an established stand of warmseason prairie grasses seeded in 1965. A mixture of big bluestem (Andropogon gerardi, Vitman), switchgrass (Panicum virgatum, L.), Indiangrass (Sorghastrum nutans, L.), and sideoats grama (Bouteloua curtipendula L.) had been seeded at 1.6, 0.5, 1.0 and $1.0 \mathrm{lb}$. of pure live seed per acre respectively.

The soil was classified as a Crofton silt loam, a Typic Usthorthent by the 7 th approximation classification system. This soil, formed under grass vegetation, occurs on moderate to steep slopes of 5 to $40 \%$ and is well drained. It is a highly eroded soil with a low organic matter content. Rapid to moderate surface runoff occurs with most rainfall intensities. Thickness of the solum ranges from 6 to 15 inches while the depth to free lime varies from 0 to 8 inches. This soil is highly calcareous ( $\mathrm{pH} 7.0$ to $8.0+$ ), has a high exchangeable $\mathrm{K}$ content (325 ppm) but is low in available $P(1.5 \mathrm{ppm})$ as measured by the Bray procedure.

Nitrogen as 33-0-0 was surface applied each year while $P$ as $0-46-0$, $\mathrm{K}$ as $0-0-60$, S as "Sol-U-Sul," and $\mathrm{Zn}$ as an NTA chelate were broadcast on alternate years. All nutrients were applied after May 15. Treatments were replicated 4 times in a randomized complete block design.

Forage yields, expressed on a dry matter basis, were recorded in early to mid-August each year from a $3 \mathrm{ft} \times 20 \mathrm{ft}$ harvested area. Plant samples were collected for analysis

Table 1. The influence of $\mathrm{N}, \mathrm{P}, \mathrm{K}, \mathrm{S}$ and $\mathrm{Zn}$ (lb./acre) on the yield (ton/acre) of a seeded mixture of warm-season prairie grasses.

\begin{tabular}{|c|c|c|c|c|c|c|c|c|c|}
\hline \multicolumn{5}{|c|}{ Treatment } & \multicolumn{4}{|c|}{ Year } & \multirow[b]{2}{*}{$\begin{array}{c}\text { 4-year } \\
\text { total }\end{array}$} \\
\hline $\mathbf{N}$ & $\mathbf{P}$ & K & $\mathbf{S}$ & $\mathrm{Zn}$ & 1967 & 1968 & 1969 & 1970 & \\
\hline - & - & - & - & - & $.23 \mathrm{a}^{1}$ & $.43 \mathrm{a}$ & $1.53 \mathrm{a}$ & $.64 \mathrm{a}$ & $2.83 \mathrm{a}$ \\
\hline 40 & - & - & - & - & $.42 \mathrm{~b}$ & $.38 \mathrm{a}$ & $1.96 \mathrm{~b}$ & $1.04 \mathrm{~b}$ & $3.80 \mathrm{~b}$ \\
\hline 80 & - & - & - & - & $.56 \mathrm{c}$ & $.44 \mathrm{a}$ & $2.59 \mathrm{c}$ & $1.32 \mathrm{bc}$ & $4.87 \mathrm{c}$ \\
\hline 80 & 20 & - & - & - & $.88 \mathrm{~d}$ & $.49 \mathrm{a}$ & $3.31 \mathrm{~d}$ & $1.48 \mathrm{~cd}$ & $6.13 \mathrm{~d}$ \\
\hline 80 & 40 & - & - & - & $.90 \mathrm{~d}$ & $.59 \mathrm{a}$ & $3.17 \mathrm{~d}$ & $1.81 \mathrm{~d}$ & $6.44 \mathrm{~d}$ \\
\hline 80 & 20 & 20 & - & - & $.84 \mathrm{~d}$ & $.52 \mathrm{a}$ & $3.48 \mathrm{~d}$ & $1.46 \mathrm{~cd}$ & $6.32 \mathrm{~d}$ \\
\hline 80 & 20 & 20 & 40 & - & $.85 \mathrm{~d}$ & $.53 \mathrm{a}$ & $3.26 \mathrm{~d}$ & $1.58 \mathrm{~cd}$ & $6.23 \mathrm{~d}$ \\
\hline 80 & 20 & 20 & 40 & 10 & $.91 \mathrm{~d}$ & $.54 \mathrm{a}$ & $3.44 \mathrm{~d}$ & $1.59 \mathrm{~cd}$ & $6.42 \mathrm{~d}$ \\
\hline
\end{tabular}

${ }_{1}^{1}$ Treatment means within any one column having the same letter are not significantly different at the $95 \%$ confidence level.

in 1967,1968 , and 1970 . The protein content of the plant tissue, as measured by the Kjeldahl procedure described by Bremner (1965) was recorded in 1967, 1968, and 1970. The samples collected in 1970 were also analyzed for $P, K$, $\mathrm{Ca}, \mathrm{Mg}, \mathrm{Zn}, \mathrm{Cu}, \mathrm{Fe}$ and $\mathrm{Mn}$ (Knudsen and Hassan, 1969) and the percentage of digestible dry matter (Tilley and Terry, 1963). In 1971, the botanical composition of the mixture was measured according to the method described by Burzlaff (1966).

\section{Results \\ Forage Yields}

Forage yields were increased by fertilization in three of the four years of the study (Table 1). Applied treatment had no effect on yields in 1968 when precipitation during the growing season was below normal. In 1967, forage production was increased by the use of both 40 and $80 \mathrm{lb}$. N/acre. The largest increase resulted from the first $40 \mathrm{lb}$. increment. The addition of $20 \mathrm{lb} . \mathrm{P} /$ acre to $80 \mathrm{lb}$. N/ acre produced an additional increase in yield, but raising the $P$ rate to $40 \mathrm{lb}$./acre had no effect.

With favorable moisture, largest forage yields were recorded in 1969 with yield trends similar to those observed in 1967. The 1970 yields were less consistent than those re- corded in 1967 and 1969, but production trends were similar. There was a clear response to the addition of $40 \mathrm{lb}$. $\mathrm{N} /$ acre with yield responses varying among the other treatments. The lack of other distinct treatment effects may have been due, in part, to the shortage of rainfall during the 1970 growing season. The addition of $\mathrm{K}, \mathrm{S}$ and Zn did not increase yields at any time.

The four-year yield totals also show the beneficial effect of the combination of $\mathrm{N}$ and $\mathrm{P}$ on forage production of the warm-season prairie grass mixture. Yields were increased approximately one ton/ acre by each $40 \mathrm{lb}$. increment of $\mathrm{N}$ without added $\mathrm{P}$. The use of $\mathbf{P}$ combined with the $\mathbf{N}$ produced an additional yield response. These data show that the combination of $\mathrm{N}$ and $\mathrm{P}$ is needed for maximum forage production. These four-year yield totals also show that $\mathrm{K}, \mathrm{S}$ and $\mathrm{Zn}$ had no measurable influence on forage yields.

\section{Analysis of Plant Tissue}

The nutrient content of the mature forage collected in 1970 was not altered by fertilizer treatment. Differences were due to random variation.

The tissue sampled in 1968 was considerably higher in protein than tissue collected in 1967 or 1970 (Table 2); but considering the low 
Table 2. The effect of fertilizer treatment (lb./acre) on the protein content (\%) of and protein produced (lb./acre) by a seeded mixture of warm-season prairie grasses.

\begin{tabular}{|c|c|c|c|c|c|c|c|c|c|c|}
\hline \multicolumn{5}{|c|}{ Treatment } & \multicolumn{3}{|c|}{ Protein content } & \multicolumn{3}{|c|}{ Protein produced } \\
\hline $\mathbf{N}$ & $\mathbf{P}$ & K & $S$ & $\mathrm{Zn}$ & 1967 & 1968 & 1970 & 1967 & 1968 & 1970 \\
\hline - & - & - & - & - & $4.64 \mathrm{a}^{1}$ & $8.12 \mathrm{a}$ & $4.30 \mathrm{a}$ & $21 \mathrm{a}$ & $71 \mathrm{a}$ & $54 \mathrm{a}$ \\
\hline 40 & - & - & - & - & $5.26 \mathrm{a}$ & $10.09 \mathrm{~b}$ & $4.66 \mathrm{a}$ & $44 \mathrm{~b}$ & $78 \mathrm{a}$ & $96 \mathrm{a}$ \\
\hline 80 & - & 一 & - & - & $5.19 \mathrm{a}$ & $10.05 \mathrm{~b}$ & $5.99 \mathrm{a}$ & $58 \mathrm{~b}$ & 91 a & $157 \mathrm{~b}$ \\
\hline 80 & 20 & 一 & - & - & $4.69 \mathrm{a}$ & $10.16 \mathrm{~b}$ & $5.20 \mathrm{a}$ & $82 \mathrm{c}$ & $105 \mathrm{a}$ & $153 \mathrm{~b}$ \\
\hline 80 & 40 & - & - & - & $4.64 \mathrm{a}$ & $10.44 \mathrm{~b}$ & $5.48 \mathrm{a}$ & $83 \mathrm{c}$ & $119 \mathrm{a}$ & $197 \mathrm{~b}$ \\
\hline 80 & 20 & 20 & - & - & $4.70 \mathrm{a}$ & $9.38 \mathrm{ab}$ & $5.42 \mathrm{a}$ & $79 \mathrm{c}$ & $96 \mathrm{a}$ & $159 \mathrm{~b}$ \\
\hline 80 & 20 & 20 & 40 & 一 & $4.73 \mathrm{a}$ & $9.12 \mathrm{ab}$ & $5.39 \mathrm{a}$ & $81 \mathrm{c}$ & 97 a & $168 \mathrm{~b}$ \\
\hline 80 & 20 & 20 & 40 & 10 & $4.64 \mathrm{a}$ & $9.87 \mathrm{~b}$ & $5.60 \mathrm{a}$ & $84 \mathrm{c}$ & $107 \mathrm{a}$ & $178 \mathrm{~b}$ \\
\hline
\end{tabular}

1 Treatment means within any one column having the same letter are not significantly different at the $95 \%$ confidence level.

yields in 1968, this observation may be explained, in part, by plant dilution. In general, fertilizer treatment had no consistent effect on the protein content of the mature tissue.

Except for 1968, fertilization increased protein production. In 1967, the use of both $\mathrm{N}$ and a combination of $\mathbf{N}$ and $P$ increased the protein yield. During this year, the two $\mathrm{N}$ rates were equally effective in their influence on the amount of protein produced. In 1970 , protein production from the application of $40 \mathrm{lb}$. N/acre was not different from that produced by the check treatment. Protein production was, however, increased by the application of $80 \mathrm{lb}$. N/acre. The use of $P$ produced no further increases. The application of $\mathrm{K}$, $\mathrm{S}$, and $\mathrm{Zn}$ had no effect on protein production throughout the study.

In order to obtain another measure of forage quality, the tissue from the 1970 harvest was analyzed for digestible dry matter. Utilizing these percentages as well as the yield data, the amount of digestible dry matter produced per acre was determined (Table 3). This data showed that fertilizer usage had no influencc on the percentage of digestible dry matter in the mature tissue. The production of in vitro digestible dry matter was increased, however, by the use of both $\mathrm{N}$ and the combination of $\mathrm{N}$ and $\mathrm{P}$.

\section{Botanical Composition}

One of the chief criticisms of fertilizing warm-season prairie grasses has been that this practice stimulates the growth of cool-season species and weeds. Although the seeded mixture included big bluestem, switchgrass, Indiangrass and sideoats grama, the predominant species after four years were big bluestem and sideoats grama (Table 4). No Indiangrass could be detected in any of the treatments. 2

The percentage of big bluestem and sideoats grama in the mixture

2 The authors wish to thank Mr. Dewey Teel, Holt County Agricultural Extension Agent, for his excellent assistance in determining the vegetation inventory. warm season prairie grasses. different at the $95 \%$ confidence level. was not altered by fertilizer treatment. Percentages of switchgrass, cool-season species, weeds and bare ground were quite variable. The largest percentage of bare ground occurred in the check treatment $(4.6 \%)$ where forage growth was much shorter and less dense.

The weed content was fairly uniform across all treatments. These data show that there were no large increases in the weed population with fertilization while the amount of cool-season species varied among treatments. There was, however, no large increase in the amount of these species resulting from fertilization.

\section{Discussion}

Previous work in Nebraska by Warnes and Newell (1969), Warnes et al. (1971), and Burzlaff et al. (1968), had shown that warm-season prairie grasses would respond to the use of $N$. The data from this study support these earlier findings. In addition, there was a marked response to the use of 20 lb. P/acre, illustrating the importance of the combination of $\mathrm{N}$ and $P$ on soils with low or very low levels of available $P$.

There was no indication of a response to $\mathrm{K}, \mathrm{S}$ or $\mathrm{Zn}$ throughout the study. Apparently, the $\mathrm{K}$ content of the soil (325 ppm) was sufficient to supply the $K$ requirements of the forage produced in
Table 3. The effect of $\mathbf{N}, \mathbf{P}, \mathrm{K}, \mathrm{S}$ and $\mathrm{Zn}$ treatments (lb./acre) on the percentage (\%) and the amount of digestible dry matter produced (lb./acre) by

\begin{tabular}{|c|c|c|c|c|c|c|}
\hline \multicolumn{5}{|c|}{ Treatment } & \multirow{2}{*}{$\begin{array}{l}\text { Digestible } \\
\text { dry matter }\end{array}$} & \multirow{2}{*}{$\begin{array}{l}\text { Digestible dry matter } \\
\text { produced }\end{array}$} \\
\hline $\mathbf{N}$ & $\mathbf{P}$ & $\mathrm{K}$ & $S$ & $\mathrm{Zn}$ & & \\
\hline - & - & - & - & - & $53.9 \mathrm{a}^{1}$ & $690 \mathrm{a}$ \\
\hline 40 & - & - & - & - & 56.2 a & $1167 \mathrm{~b}$ \\
\hline 80 & - & - & - & - & $57.9 \mathrm{a}$ & 1529 bc \\
\hline 80 & 20 & - & - & - & $55.8 \mathrm{a}$ & $1653 \mathrm{c}$ \\
\hline 80 & 40 & - & - & - & $58.8 \mathrm{a}$ & $2114 d$ \\
\hline 80 & 20 & 20 & - & - & $57.5 \mathrm{a}$ & $1679 \mathrm{c}$ \\
\hline 80 & 20 & 20 & 40 & - & $54.8 \mathrm{a}$ & 1722 c \\
\hline 80 & 20 & 20 & 40 & 10 & $56.1 \mathrm{a}$ & $1776 \mathrm{~cd}$ \\
\hline
\end{tabular}

${ }^{1}$ Treatment means within any one column having the same letter are not significantly 
Table 4. The effect of fertilizer treatment (lb./acre) on the vegetative composition (\%) of a mixture of warm-season prairie grasses.

\begin{tabular}{|c|c|c|c|c|c|c|c|c|c|}
\hline & & & & & \multicolumn{5}{|c|}{ Composition } \\
\hline \multicolumn{5}{|c|}{ Treatment } & \multirow{2}{*}{$\begin{array}{c}\text { Big } \\
\text { bluestem }\end{array}$} & \multirow{2}{*}{$\begin{array}{c}\text { Sideoats } \\
\text { grama }\end{array}$} & \multirow{2}{*}{$\begin{array}{l}\text { Switch- } \\
\text { grass }\end{array}$} & \multirow{2}{*}{$\begin{array}{l}\text { Cool } \\
\text { season } \\
\text { grasses }\end{array}$} & \multirow[b]{2}{*}{ Weeds } \\
\hline $\mathbf{N}$ & $\mathbf{P}$ & $\mathbf{K}$ & $\mathrm{S}$ & $\mathrm{Zn}$ & & & & & \\
\hline - & - & - & - & - & $63.4 \mathrm{a}^{1}$ & $29.2 \mathrm{a}$ & .4 & 0.0 & 0.0 \\
\hline 40 & - & - & - & - & $62.5 \mathrm{a}$ & $36.7 \mathrm{a}$ & 0.0 & 0.0 & .4 \\
\hline 80 & 一 & - & - & - & $47.9 \mathrm{a}$ & $49.2 \mathrm{a}$ & .4 & .4 & .8 \\
\hline 80 & 20 & 一 & - & - & $65.8 \mathrm{a}$ & $31.3 \mathrm{a}$ & 2.1 & .4 & .4 \\
\hline 80 & 40 & - & - & - & $69.2 \mathrm{a}$ & $32.5 \mathrm{a}$ & 0.0 & .4 & .4 \\
\hline 80 & 20 & 20 & - & - & $64.6 \mathrm{a}$ & $32.5 \mathrm{a}$ & 1.7 & 1.3 & 0.0 \\
\hline 80 & 20 & 20 & 40 & - & $61.7 \mathrm{a}$ & $37.1 \mathrm{a}$ & .9 & 0.0 & .4 \\
\hline 80 & 20 & 20 & 40 & 10 & $69.6 \mathrm{a}$ & $25.8 \mathrm{a}$ & 3.8 & .4 & .4 \\
\hline
\end{tabular}

1 Treatment means within any one column having the same letter are not significantly different at the $95 \%$ confidence level.

this study. Because of the low organic matter content and the calcareous nature of the soil, it was thought that the grasses might respond to the use of $S$ and $Z n$. The data show, however, that neither nutrient increased forage yields.

The fertilizer applied over the four-year period at the rates shown did not change the soil level of $N$, $\mathrm{P}$ and $\mathrm{K}$ as measured by standard laboratory procedures (data not shown). In addition, there was very little, if any, downward movement of $\mathrm{N}$ and $\mathrm{P}$. Calculations of nutrient recoveries show that only small amounts of the added fertilizer were recovered in the plant tissue. Either higher rates will have to be applied to bring about changes in soil nutrient levels or different laboratory procedures will be needed to detect the small changes that may take place.

In addition to yield, these nutrients were evaluated with respect to their effect on forage quality. In this study, fertilization had no effect on the protein content of the forage tissue. These data are not in agreement with reported work with bluestem range by Moser and Anderson (1964) or native Northern Plains rangeland by Rogler and Lorenz (1957). It should be pointed out here that protein determinations were made on mature tissue collected at harvest. It is highly possible that differences in protein content could have been detected if samples had been collected at earlier stages of maturity.

The fact that the percentage of digestible dry matter in the tissue was not altered by fertilization would agree with conclusions reached by Blaser (1964) who, after reviewing the literature, reported that stage of maturity rather than fertilization had a greater influence on the digestible dry matter in forage tissue.

After four years of fertilization the primary grasses of the mixture were big bluestem and sideoats grama and the percentage of each was not altered by fertilization. No Indiangrass could be detected and the percentage of switchgrass was rather small in all treatments. It appears that factors other than fertilization were responsible for the failure of these two grasses to become established.

Fertilization did not increase encroachment by cool-season grasses or weeds. Researchers from other states, however, have reported that fertilization of established stands of warm-season grasses has increased growth of cool-season species (Owensby et al., 1970) and weeds (Huffine and Elder, 1960). In this study, the lack of encroachment by the undesirable plants may be due, in part, to the fact that fertilization was delayed until after May 15th of each year. It was thought that by delaying application, the nutrients would be more readily used during the period of active growth of the warmseason species. Studies are now in progress to determine the effect of timing of fertilizer applications on the yield and quality of the warm-season prairie species.

\section{Literature Cited}

Black, A. L. 1968. Nitrogen and phosphorus fertilization for production of crested wheatgrass and native grass in northeastern Montana. Agron. J. 60:213-216.

Blaser, R. E. 1964. Symposium on Forage Utilization: Effects of fertility levels and stage of maturity on forage nutritive values. J. Anim. Sci. 23:246-253.

Bremner, J. M. 1965. Total Nitrogen. In C. A. Black et al. (ed.) Methods of Soil Analysis, Agronomy 9:1149-1178.

Burzlaff, D. F. 1966. The focalpoint technique of vegetation inventory. J. Range Manage. 19:222-223.

Burzlaff, D. F., G. W. Fick, and L. R. Rittenhouse. 1968. Effect of nitrogen fertilization on certain factors of a western Nebraska range ecosystem. J. Range Manage. 21: 21-24.

Goetz, H. 1969. Composition and yields of native grassland sites fertilized at different rates of nitrogen. J. Range Manage. 22:384-390.

Hubbard, W. A., and J. L. Mason. 1967. Residual effects of ammonium nitrate and ammonium phosphate on some native ranges in British Columbia. J. Range Manage. 20:1-5.

Huffine, W. W., and W. C. Elder. 1960. Effect of fertilization on native grass pastures in Oklahoma. J. Range Manage. 13:34-36.

Johnston, A., A. D. Sмith, L. E. Lutwick, AND S. SMOLIAK. 1968. Fertilizer response of native and seeded ranges. Can. J. Plant Sci. 48: 467-472.

Knudsen, D., ANd N. Hassan. 1969. Soil plant and water chemical procedures. (mimeo) Univ. of Neb., Lincoln, Neb.

Moser, L. E., AND K. L. ANDERson. 1964. Nitrogen and phosphorus fertilization of bluestem range. Trans. Kansas Acad. Sci. 67:613-616.

OWensBy, C. E., R. M. Hyde, AND K. 
L. Anderson. 1970. Effects of clipping and supplemental nitrogen and water on loamy upland bluestem range. J. Range Manage. 23:341316.

Rauzi, F., R. L. Lang, and L. I. Painter. 1968. Effects of nitrogen fertilization on native rangland. J. Range Manage. 21:287-291.
Read, D. W. L. 1969. Residual effects from fertilization on native range in southwestern Saskatchewan. Can. J. Soil Sci. 49:225-230.

Rogler, G. $\Lambda$., AND R. J. Lorenz. 1957. Nitrogen fertilization of northern great plains rangelands. J. Range Manage. 10:156-160.

Tilley, J. M. A., AND R. A. Terry.
1963. A two-stage technique for the in vitro digestion of forage crops. $\mathrm{J}$. Brit. Grassland Soc. 18:104-111.

Warnes, D. D., L. C. Newell, and W. J. Moline. 1971. Performance evaluation of some warm-season prairie grasses in Nebraska environments. Res. Bull. 241. Neb. Agr. Exp. Sta. 